\title{
Prediction of Client Support on Contractor Performance as a Critical Success Factor
}

\author{
Johnson Matu*, Augustine Mwangi Gatotoh, James Mushori \\ Open Distance and eLearning Campus, University of Nairobi, Nairobi, Kenya \\ Email: ^matupec@gmail.com
}

How to cite this paper: Matu, J., Gatotoh, A.M. and Mushori, J. (2021) Prediction of Client Support on Contractor Performance as a Critical Success Factor. Journal of Building Construction and Planning Research, 9, 77-89.

https://doi.org/10.4236/jbcpr.2021.91007

Received: January 25, 2021

Accepted: March 28, 2021

Published: March 31, 2021

Copyright $\odot 2021$ by author(s) and Scientific Research Publishing Inc. This work is licensed under the Creative Commons Attribution International License (CC BY 4.0).

http://creativecommons.org/licenses/by/4.0/

\begin{abstract}
The aim of this study was to assess the influence of client support on performance of contractors within the road construction industry in Kenya. The study adopted descriptive survey research design and correlation research design. The target population was 156 selected from road contractors, engineers working in road authorities, technical auditors and consultants in the road sector. Stratified and proportionate sampling techniques were employed in coming up with a sample size of 62 respondents drawn from a target population of 156. From the simple linear regression conducted, the findings revealed that client support influences the performance of contractors in the road construction sector. Thus, we recommend that client support is highly needed to avoid issues such as delayed payment that would adversely affect performance of contractors in the road construction industry. This will subsequently lead to timely completion of roads, achieving cost effective and quality road projects.
\end{abstract}

\section{Keywords}

Client Support, Road Contractors, Contractor Performance

\section{Introduction}

The responsibility of achieving success in the implementation of a construction project largely depends on the contractor's performance. However, delays in project completion and poor performance in the construction industry have been experienced in many projects globally and more especially in the developing countries [1] [2] [3] [4] [5].

In Malaysia, $17.3 \%$ of construction projects experience more than three months delay and some of them are abandoned [3]. The factors causing delays include: labour shortage, financial difficulties, construction mistakes and defec- 
tive works. A study by Bitamba and An was aimed to identify and evaluate the most significant key performance indicators that affect construction projects in the Congo, and to classify them using the Relative Importance Index (RII) [6]. It emerged that the factors that affect construction projects in Congo are: project design, contractor management, client management, contract and project scheduling. The design team's experience and skills have an effect on factors related to the design. On the part of the client or the project owner, delayed payments followed by delivery of construction site influenced contractor performance. A related but separate survey in Ghana seems to confirm this view, where financial difficulties were ranked among the top three most probable effects of late payments to contractors [4].

In Kenya, implementation of projects within budget and time stands at $20.8 \%$ imputing that $79.2 \%$ projects do not meet this criteria [7]. This is attributed to weak project design, insufficient implementing capacity, weak project management and political interference. Therefore, factors influencing performance of contractors are very critical to any construction firm. Xiao and Proverbs stated that contractor performance can be realized when clients attempt to reduce project's design variations in the course of construction [8].

The constructions industry, being complex, comprises various parties as project client (owner), project contractor, project consultant, project stakeholder, and the regulator [9]. The role of client is to capture various challenges in construction projects and also interact and communicate with diverse key stakeholders for the success of construction of projects [10]. For example, in Kenya, the main road agencies are Kenya National Highway Authority (KeNHA), Kenya Urban Roads Authority (KURA) and Kenya Rural Roads Authority (KeRRA) mandated with construction and maintenance of road projects as clients. It is expected they support the road contractors in carrying out tasks related to design review and provision of project funds. Chigangacha and Haupt argue that clients in private sector tend to get involved in projects than their counterparts in public sector [11]. They further state that client involvement is predominant in pre-construction and post-construction phases.

Considering that a number of studies have presented issues of project implementation and performance, none has identified and addressed the issue of client support. This study was therefore guided by null hypothesis $\left(\mathrm{H}_{0}\right)$ that there is no relationship between client support and contractor performance.

\section{Literature Review}

Literature shows that delay in project completion has been a subject of concern to various researchers for decades. Since delay is directly associated with cost and time overrun, thus it is a matter of concern for stakeholders in the construction sector. Some of the studies in various contexts are covered in this section. 


\subsection{Gap in Contractor Performance}

Different contexts have produced related challenges for project completion with small contextual differences. A study by Thorat, et al. in India, determined the top ten causes of delay in construction projects [12]: 1) Shortage of skilled manpower and labour; 2) Improper planning of contractor; 3) Poor site management of contractor; 4) Delay in payment by client; 5) Inadequate experience of consultant; 6) Legal disputes; 7) Shortage of materials; 8) Delay in preparation and approval of drawings by consultant; 9) Late procurement of materials; 10) Low financial capability of contractor. Seven main effects of delay were: 1) Time overrun; 2) Cost overrun; 3) Reduction of profit; 4) Poor quality of project; 5) Abandonment of project; 6) Dispute; 7) Arbitration. Sambasivan and Soon identified the delay factors and their impact on project completion in Malaysian construction industry. Ten most causes identified were [13]: a) contractor's improper planning b) contractor's poor site management c) contractor's inadequate experience d) delay in payment by client e) problem with subcontractors $\mathrm{f}$ ) shortage in material g) labour supply $\mathrm{h}$ ) equipment availability and failure i) lack of communication j) mistakes and rework. As already aforementioned, the current study will focus on client support and contractor performance. Some of the key performance factors (KPIs) relating to project performance and not contractor performance are cost, time, quality, safety and health [14].

A study by Alinaitwe on assessment of clients' performance in having an efficient building process in Uganda revealed that factors such as delayed payment by clients, lack of support for training the workers and poor or irregular attendance of meetings affected contractors' performance [15]. Similarly, Simaya and Maro noted that cost, quality and time remain important aspects that need to be considered during project execution phase to contribute towards performance [16]. Mushori, Rambo and Wafula revealed performance of road construction infrastructure projects can as well be measured in terms of quality of the completed projects [17].

\subsection{Client Support}

Client support is by show of the role assumed to ensure timely completion and cost effectiveness of the road projects hence contributing to a positive image on contractor's performance. Jegtap and Kamble study on construction firms affirmed the significance of demarcating roles of client and contractor roles within the construction supply chain so as to enhance project performance [18]. Alinaitwe noted that the success of project depends as much on the client as it does on the consultants and contractors [15]. Client support include but is not limited to; budget allocation and prompt payments of interim progress payments [19] [20], provision of accurate project designs and approvals [21] [22], prompt issue of instructions to commence the construction work [21], early land acquisition of areas required for the construction of roads [23], project supervision to ensure quality including achievement of value for money and timely taking over inspec- 
tion and certification of works once project is completed [23] [24].

One of the most important client support role is the payment for work done by a contractor in a project initiated by the client. Byaruhanga and Basheka observed that delay of contractors' payment affects timelines in delivery of services [25]. Ramachandra argues that the performance of the participants involved and the product output is dependent on the promptness and regularity of payment [19]. He further suggests that failure to pay in the construction industry may be put in three categories; delay in paying one or more certificates, reduction in value of certificates or invoices, and not paying at all. Payments in the construction industry are seen as monetary consideration for the contractors' performance for work done. Tran and Carmichael concluded that late and intermittent payments or non-payments or both can critically affect performance of contractors [26]. Several studies have established that the character and the diverse types of contractual payments that might be delayed or defaulted by the employer may additionally be classified as interim, stage or milestone, advance payments, payment of retention monies and final payments [4] [19] [27] [28] [29]. Governments or owners of projects should allocate adequate budgets to a project to enable its completion since it cannot continue with inadequate financing, and would affect performance of contractors to meet planned targets [20].

Another key support area is accurate project design and approval. This is critical in project execution as it eliminates the need to vary the contract. The government is also responsible for approval of the project which facilitates contractor performance. In a study by Arshi and El-Sayegh, the perspective of contractors and consultants was analysed to rank the causes of delays based on their Relative Importance Index. Contractors and consultants were in agreement on the most significant causes of delays [21]. It was noted $50 \%$ of UAE construction projects face delay challenges and untimely completions of projects. Factors associated with delays are drawings approval, poor or inadequate planning and decision making process taking longer by the project owner. A qualitative study by Sperling et al. found that project success was a result of effective communication, not forgetting consultation and sharing of information between the client, designer and constructor were vital to project success [30].

Additionally, there is a need for contractors to be given maximum support in the possession of land for the construction without any encumbrances. This means that the required land must be acquired at the early stages of the project cycle. In India, megaprojects suffer from both time and cost overruns primarily because of environmental and land acquisition controversies [23].

Trigunarsyah and Al-Solaiman stated that low client involvement can have serious negative impact on the overall projects' outcomes particularly completion time and project quality [31]. It is however argued that client-consultant coordination has a significant effect on performance through goal congruence and building trust [32]. Gunduz and Almuajebh listed client related factors for sustainable construction project management. These include [33]: client's expe- 
rience in the construction industry, mechanism for financial payments and finally client's influence or representative. Late payment is pointed out by Simaya and Maro as a challenge that faces local government authorities hence not being able to achieve value for money [34].

A study by Halwatura and Pathiranage revealed that locally based road construction projects in Sri Lanka experience between $56 \%$ and $88 \%$ of average time overrun compared to planned project duration as a result of financial problems on the part of the owner (client) and the contractor [35]. The findings resonate with Mushori et al. who found that road performance is correlated with financial ability [17]. All these, however, cannot be achieved without the support or involvement of the client (owner of the road projects).The adduced evidence on the importance of client role in supporting contractor performance is not empirically supported hence the current study that aims to test the relationship between these two variables, client support and contractor performance in road construction projects.

\subsection{Stakeholders Theory}

This study is based on stakeholder's theory which, as a field of research, has tended to focus on planning and managing the complex array of activities required for delivering a construction project, such as a road or building [36]. The theory has its genesis in strategic organization, and has been applied in several areas of enquiry as well in corporate social responsibility [37], including on construction project organization lately [38].

Construction business, as an area of study, tends to focus on scheduling and organizing the multifaceted assortment of activities necessary to complete a construction project. Being able to manage construction stakeholder's hopes and concerns is a critical skill for managers of construction projects. Failure to tackle hopes and concerns of stakeholders in a construction project has resulted in innumerable failure of projects [38], principally for the reason that stakeholders in construction have a tendency to obtain resources and ability to impede construction. Meeting the expectation of stakeholder is critical to successful execution of construction projects. Stakeholders include owners of project, consultants, subcontractors, suppliers, funding bodies, users, owners, employees and project managers. As a consequence, a vigorous construction organization literature has developed on how to recognize and manage stakeholder welfare and interactions. Stakeholder theory is preferred in this study to aid in establishing important factors that have influence contractor performance within the road construction industry in Kenya.

\section{Methodology}

This study employed a descriptive survey research design and correlation research design. The design was employed to determine the relationship between the predictor variable and the outcome variable [39]. Study population total was 
156 representing 51 road contractors, 40 consulting engineers, 60 engineers from road authorities and 5 technical auditors participating in road construction in Kenya. The road authority engineers were sampled from the following agencies: Kenya National Highway Authority (KeNHA), Kenya Urban Roads Authority (KURA) and Kenya Rural Roads Authority (KeRRA). In this study, stratified sampling was applied for grouping the subjects into four strata, thereby using proportionate sampling to pick sample size from each stratum. Out of target population of 156, a sample of 62 was obtained, representing 40\%. According to Gay and Airasian a sample size between $10 \%-40 \%$ is sufficient for analysis [40]. The sampling techniques were applied so as to obtain a representative sample because the study population did not constitute a homogeneous group. The data was collected using self-administered questionnaires through simple random sampling technique. The Cronhach's alpha for client support was $\alpha=0.748$ above 0.7 thus meeting the threshold by Gliem and Gliem that a value of 0.7 is acceptable reliability coefficient [41].

A total of 51 questionnaires were filled and returned representing $82.3 \%$ of the total number of questionnaire distributed having surpassed a pass mark of $70 \%$ exceptional [42]. Collected data was coded and entered into Statistical Packages for Social Scientists (SPSS) Version (21.0) and analyzed using descriptive statistics. The means and standard deviations were presented as well as the interpretations thereof. Simple linear regression by use Analysis of Variance (ANOVA) aided in performing and establishing the strength of predictor variable on outcome variable.

\section{Results and Discussions}

The results of the study are presented in three parts; contractor performance, client support, skilled manpower and training. The results are presented using means, standard deviation, and correlation and regression analysis.

\subsection{Contractor Performance}

The study sought to establish how contractor performance is influenced by client support. The results are shown in Table 1.

Results presented in Table 1 show that most of the respondents strongly agreed that the following factors hinder contractor performance in terms of

Table 1. Contractor performance.

\begin{tabular}{ccc}
\hline Statements & Mean & Std. Dev. \\
\hline Delayed Payment affects operations & 4.73 & 0.49 \\
Variation in scope affects quality of work done & 4.22 & 0.70 \\
Prompt contract approvals helps in hiring skilled personnel & 4.16 & 0.76 \\
Contractor experience land acquisition issues that affect completion time & 4.45 & 0.70 \\
Ability to deal with weather conditions to produce quality road projects & 3.96 & 0.66 \\
Contractor experience cost Overruns & 4.08 & 0.72 \\
\hline
\end{tabular}


delivering road projects within time, budget and quality; highly ranked was delayed payment $($ mean $=4.73)$. This supports the findings by Alinaitwe (2008) that delay in paying contractors affects their performance. Second was land acquisition $($ mean $=4.45)$. Third was variation in scope $($ mean $=4.22)$. Fourth was delayed approvals caused by client (mean $=4.16)$ and fifth was cost overruns $($ mean $=4.08)$. The last one was weather conditions (mean $=3.96)$. The findings are consistent with Thorat et al. (2017) who indicated that contractor face myriad challenges that affect their performance.

\subsection{Client Support and Contractor Performance}

The study sought to establish the extent to which client support influence construction of roads projects. The results are shown in Table 2 .

Results presented in Table 2 show that majority of the respondents strongly agreed that prompt payments and approvals facilitates timely project completion and irregular funds disbursements cause project delays and or stalling as shown by a mean of 4.04 in each case. This finding supports Byaruhanga and Basheka (2017) who found that delay in payments adversely affects timelines allocated for delivering the services. Majority of study participants pointed out issues of cost of overrun, project disputes, project arbitration and ligation costs and project abandonment are essentially triggered by insufficient support by the client (mean $=3.84)$. Alinaitwe $(2008)$ found that clients and their representatives, as part of the stakeholders, do not regularly attend meetings.

The findings of the current study are consistent with Ramachandra, (2013) who argues that the performance of the participants involved and the product output is dependent on the promptness and regularity of payment. These findings are also in agreement with Tran and Carmichael (2013) who determined that late and intermittent payments and/or non-payments can critically affect performance of contractors.

\subsection{Inferential Analysis}

The inferential analysis was performed by use correlation analysis (Table 3 ) and regression analysis (Table 4).

\subsubsection{Correlation Analysis}

Correlation analysis was performed using Karl Pearson's Product Moment to

Table 2. Client support and contractor performance.

\begin{tabular}{ccc}
\hline Statements & Mean & Std. Dev. \\
\hline Prompt payments and approvals facilitates timely project completion & 4.04 & 1.23 \\
Stakeholders involvement aid in smooth project implementation & 3.84 & 1.05 \\
Irregular funds disbursements causes project delays and/or stalling & 4.04 & 1.18 \\
$\begin{array}{c}\text { Insufficient support causes project costs overrun, disputes, arbitration } \\
\text { costs, litigation and project abandonment }\end{array}$ & 3.88 & 1.07 \\
\hline
\end{tabular}


Table 3. Correlations analysis.

\begin{tabular}{cccc}
\hline \multicolumn{2}{c}{ Variables } & Client Support & Contractor Performance \\
\hline \multirow{2}{*}{ Client Support } & Pearson Correlation & 1 & $0.287^{*}$ \\
& Sig. (2-tailed) & & 0.041 \\
& $\mathrm{n}$ & 51 & 51 \\
Contractor Performance & Pearson Correlation & $0.287^{*}$ & 1 \\
& Sig. (2-tailed) & 0.041 & 51 \\
\hline
\end{tabular}

${ }^{*}$ Correlation is significant at the 0.05 level (2-tailed).

establish the relationship between the predictor and the outcome variables (Table 3).

The results in Table 3 show the relationship of client support (CS)to be significant positive and moderate strong with contractor performance $(\mathrm{CP})$ given coefficient (R) for CS is 0.287 , whereas the p-values are 0.041 (CS)less than 0.05 level of significance. This implies that the predictor CS has some influence on contractor performance. The findings are in line with Alinaitwe that client support is necessary for project success [15]. The findings are also in line with Bitamba and An who opined that contractor performance is influenced by client management [6].

\subsubsection{Regression Analysis}

The study employed simple linear regression to test the study hypothesis [43], which was stated in null $\left(\mathrm{H}_{\mathrm{o}}\right)$ form (Table 4).

$\mathrm{H}_{0}$ : There is no relationship between client support and contractor performance.

$\mathrm{H}_{1}$ : There is a relationship between client support and contractor performance.

The regression equation used was as follows:

$$
Y=\beta_{0}+\beta_{1} X_{1}+\varepsilon
$$

where $Y=\mathrm{CP}$

$$
\begin{aligned}
& X_{1}=\text { CS } \\
& B_{0}=\text { Constant term } \\
& B_{1}=\text { Beta coefficients } \\
& \varepsilon=\text { Error term }
\end{aligned}
$$

From Table 4, the ANOVA was used to establish goodness of fit of the model. The calculated $\mathrm{F}(4.405)$ was greater than the critical value of $\mathrm{F}=4.038$ confirming that the model was fit. The coefficient of determination, adjust R-Square of 0.082 implies that $8.2 \%$ of the variance in contractor performance is explained by both CS. The unstandardized beta (B) value for CS was 0.138 . This implies that a unit increase in contractor performance corresponds to $13.8 \%$ increase in CS. This percentage suggests that more needs to be done to ensure that client support enhances contractor performance. This could be achieved through open 
Table 4. Regression analysis.

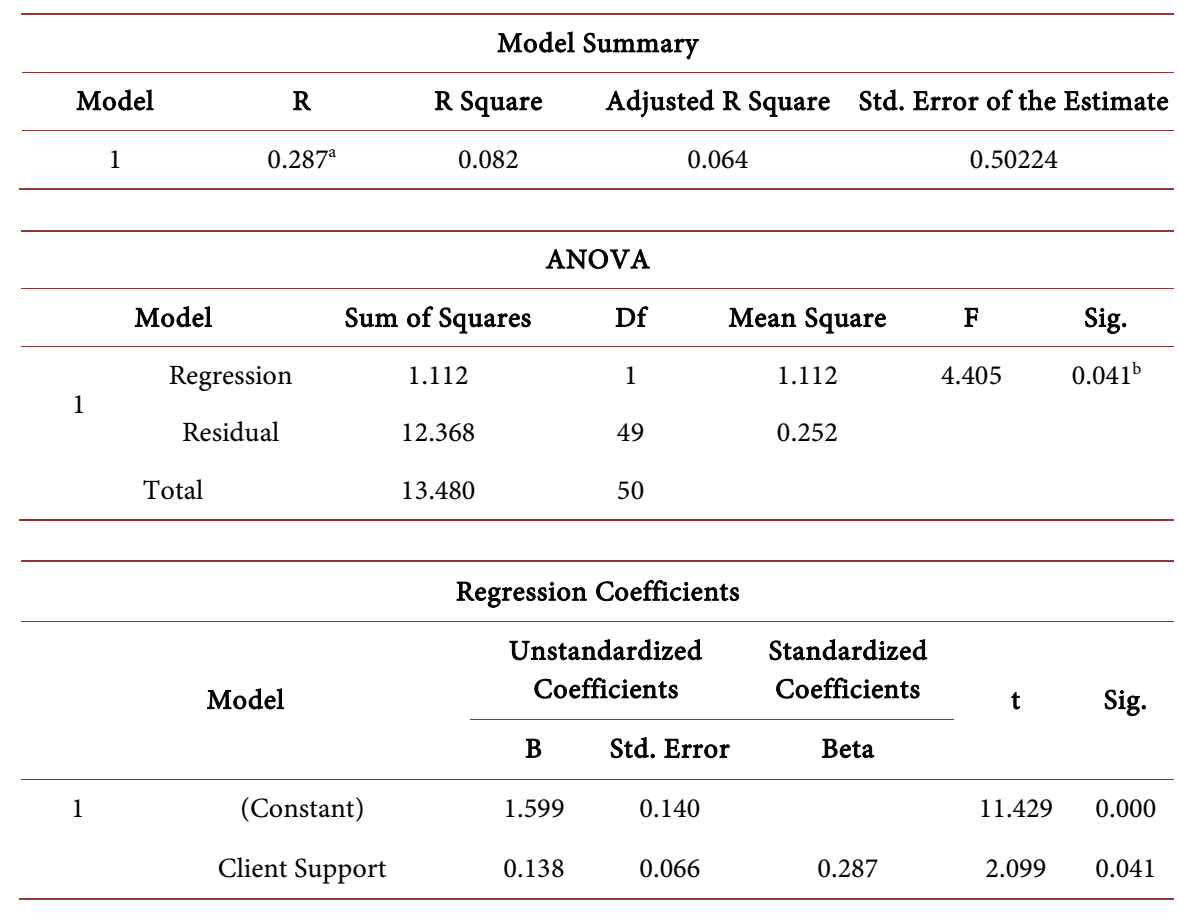

Predictors: (constant), Client Support. Dependent Variable: Contractor Performance

channels of communication [30]. The regression equation to estimate the contractor performance (CP) earlier stated as: $Y=B_{0}+B_{1} X_{1}+\mathcal{E}$ was substituted as follows:

$$
\mathrm{CP}=1.599+0.138
$$

The findings provide evidence that client support greatly influence contractor performance. In this respect, the null $\left(\mathrm{H}_{0}\right)$ hypothesis was rejected and alternate $\left(\mathrm{H}_{1}\right)$ hypothesis accepted that, there is a relationship between client support and contractor performance. The study findings that CS is good predictor of contractor performance is in line with former studies conducted in the other countries [5] [20] [21].

\section{Conclusions}

The study makes the following conclusions:

- That availability of client support enhances the performance of contractors in the road construction sector. Prompt payments and approvals is considered very crucial in facilitating timely project completion and

- That insufficient support is likely to cause project costs overrun, disputes, arbitration costs, litigation and project abandonment.

\section{Recommendations}

The study makes the following recommendations:

- There is need for the government and other key players in the construction sector to develop clear policies on client involvement and support based on 
revelation that stakeholder/client support enhanced the implementation of road construction projects.

- In order to alleviate problems associated with delayed payments, there should be effective funding of project by the client to avoid unnecessary time overruns which eventually lead to cost overruns and delayed completion of road construction projects which have a bearing on poor performance of road contractors.

- Client in conjunction with the consultants and contractors should endeavor to work together to build the capacity of the hired team for successful project implementation. Where possible, on-site training should be offered so that quality products are delivered. Besides, such trainings would ensure minimum wastage of materials by the project team thus controlling costs.

\section{Acknowledgements}

We thank government representatives and the technical auditors from road construction authorities (KENHA, KURA and KERRA) and not forgetting Roads and Civil Engineering Contractors Association (RACECA) that provided us with a list of road contractors and consulting engineers who took part in the survey. All those who have not been mentioned but played a role in this study are most appreciated.

\section{Conflicts of Interest}

The authors declare no conflicts of interest regarding the publication of this paper.

\section{References}

[1] Aftab, H.M., Ismail, A.R. and Ade, A.A.A. (2012) Time and Cost Performance in Construction Projects in Southern and Central Regions of Peninsular Malaysia. International Journal of Advances in Applied Sciences, 1, 45-52. https://doi.org/10.11591/ijaas.v1i1.537

[2] Tawil, N.M., Khoiry, M.A., Arshad, I., Hamzah, N., Jasri, M.F. and Badaruzzaman, W.H.W. (2013) Factors Contribute To delay Project Construction in Higher Learning Education, Case Study UKM, Research. Journal of Applied Sciences, Engineering and Technology, 5, 3112-3116.

[3] Ali, A.S., Smith, A., Pitt, M. and Choon, C.H. (2007) Contractors' Perception of Factors Contributing to Project Delay: Case Studies of Commercial Projects in Klang Valley, Malaysia. Journal of Design and Built Environment, 7, 43-57.

[4] Ansah, S.K. (2011) Causes and Effects of Delayed Payments by Clients on Construction Projects in Ghana. Journal of Construction Project Management and Innovation, 1, 27-45.

[5] Bilau, A.A., Ajagbe, A.K., Habila. H. and Sholanke, A.B. (2015) Review of Shortage of Skilled Craftsmen in Small and Medium Construction Firms in Nigeria. Journal of Environment and Earth Science, 5, 98-110.

[6] Bitamba, B.F. and An, S.H. (2020) Study on Factors Affecting the Performance of Construction Projects in the Democratic Republic of the Congo. South African 
Journal of Industrial Engineering, 31, 12-25. https://doi.org/10.7166/30-4-2193

[7] Nyika, D. (2012) An Analysis of the Causes of Failures in the Implementation of Projects in Kenya. Africa Habitat Review, 6, 379-388.

http://erepository.uonbi.ac.ke/bitstream/handle/11295/97982/Nyika_An\%20Analysi s\%20of\%20the $\% 20$ Causes $\% 20$ of $\% 20$ Failures\%20in\%20the\%20Implementation $\% 20$ of\%20Projects $\% 20 \mathrm{in} \% 20$ Kenya.pdf? sequence $=1$ \&isAllowed $=\mathrm{y}$

[8] Xiao, H. and Proverbs, D. (2003) Factors Influencing Contractor Performance: An International Investigation. Engineering, Construction and Architectural Management, 10, 322-332. https://doi.org/10.1108/09699980310502937

[9] Abbasbhai, M.J. and Patel, A.S. (2020) Factor Affecting Performance of Construction Projects. International Research Journal of Engineering and Technology, 7, 2344-2351.

[10] Challender, J. and Whitaker, R. (2019) The Client Role in Successful Construction Projects. Routledge, London. https://doi.org/10.1201/9781315164458

[11] Chigangacha, P.S. and Haupt, T.C. (2017) Effectiveness of Client Involvement in Construction Projects: A Contractor Perspective. 11th Built Environment Conference, Durban, 6-8 August 2017, 249-266.

[12] Thorat, S., Khandar, M. and Kanase, A.K. (2017) Exploratory Study of Causes and Effects of Delay in Indian Residential Projects. International Research Journal of Engineering and Technology, 4, 2302-2311.

[13] Sambasivan, M. and Soon, Y.W. (2007) Causes and Effects of Delays in Malaysian Construction Industry. International Journal of Project Management, 25, 517-526. https://doi.org/10.1016/j.ijproman.2006.11.007

[14] Soewin, E. and Chinda, T. (2018) Factors Affecting Construction Performance: Exploratory Factor Analysis. IOP Conference Series. Earth Environmental Science, 140, Article I D : 012102. https://doi.org/10.1088/1755-1315/140/1/012102

[15] Alinaitwe, H.M. (2008) An Assessment of Clients' Performance in Having and Efficient Building Process in Uganda. Journal of Civil Engineering and Management, 14, 73-78. https://doi.org/10.3846/1392-3730.2008.14.1

[16] Simaya, H. and Maro, G. (2018) Assessment of the Performance of Value for Money for Building Projects in Local Government Authorities in Tanzania. International Journal of Construction Engineering and Management, 7, 101-112.

[17] Mushori, J., Rambo, C.M. and Wafula, C.M. (2020) Evaluation of Contractors' Financial Ability: A Remedy for Performance of Road Construction Infrastructural Projects for Sustainable Cities. Journal of Sustainable Development, 13, 86-98. https://doi.org/10.5539/jsd.v13n6p86

[18] Jagtap, M. and Kamble, S. (2019) The Effect of the Client-Contractor Relationship on Project Performance. International Journal of Productivity and Performance Management, 69, 541-558.

[19] Ramachandra, T. (2013) Exploring Feasible Solutions to Payment Problems in the Construction Industry in New Zealand. Auckland University of Technology, Auckland.

[20] Siti, J.S. and Rosli, R.A. (2010) Contractor's Right of Action for Late or Non-Payment by the Employer. Journal of Surveying, Construction \& Property, 1, 65-95.

[21] Arshi, S.F. and El-Sayegh, S.M (2006) Significant Factors Causing Delay in the UAE Construction Industry. Construction Management and Economics, 24, 1167-1176. https://doi.org/10.1080/01446190600827033

[22] Flyvbjerg, B, (2005) Design by Deception: The Politics of Megaproject Approval 
Harvard Design Magazine, No. 22, 50-59. https://ssrn.com/abstract=2238047

[23] Raghuram, G., Bastian, S. and Sundaram, S.S. (2011) Megaprojects in India: Environmental and Land Acquisition Issues in the Road Sector. In: Brunn, S., Ed., Engineering Earth, Springer, Dordrecht, 601-615.

https://doi.org/10.1007/978-90-481-9920-4_34

[24] Cunningham, T. (2017) Cost Control during the Construction Phase of the Building Project: The Consultant Quantity Surveyor's Perspective. Dublin Institute of Technology, Dublin.

[25] Byaruhanga, A. and Basheka, B. (2017) Contractors Monitoring and Performance of Road Infrastructure Projects in Uganda: A Management Model. Journal of Building Construction and Planning Research, 5, 30-44.

https://doi.org/10.4236/jbcpr.2017.51003

[26] Tran, H. and Carmichael, D.G. (2013) A Contractor's Classification of Owner Payment Practices. Engineering, Construction and Architectural Management, 20, 29-45. https://doi.org/10.1108/09699981311288664

[27] Fleming, Q.W. and Koppelman, J.M. (2001) Earned Value for the Masses: A Practical Approach. PM Network, 15, 28-32.

[28] Uff, J. (2009) Construction Law. 10th Edition, Thomson Reuters, London.

[29] Ashworth, A. (2012) Contarctual Procedures. 6th Edition, Pearson Education Limited.

[30] Sperling, L.M., Charles, M.B., Ryan, R.A. and Brown, K.A. (2008) Driving Safety: Enhancing Communication between Clients, Constructors and Designers. 3rd International Conference of the Cooperative Research Centre (CRC) for Construction Innovation-Clients Driving Innovation: Benefiting from Innovation, Gold Coast, 12-14 March 2008, 1-15.

[31] Trigunarsyah, B. and Al-Solaiman, S. (2016) The Impact of Client Involvement on Project Performance: Case of the Kingdom of Saudi Arabia. CIB World Building Congress 2016, Vol. 5, Tampere, 30 May-3 June 2016, 258-269.

[32] Liberatore, M.J. and Luo, W. (2007) The Effect of Client-Consultant Coordination on is Project Performance: An Agency Theory Perspective. 2007 Portland International Conference on Management of Engineering \& Technology, Portland, 5-9 August 2007, 2064-2073. https://doi.org/10.1109/PICMET.2007.4349537

[33] Gunduz, M. and Almuajebh, M. (2020) Critical Success Factors for Sustainable Construction Project Management. Sustainability, 12, 1990. https://doi.org/10.3390/su12051990

[34] Simaya, H. and Maro, G. (2018) Assessment of the Performance of Value for Money for Building Projects in Local Government Authorities in Tanzania. International Journal of Construction Engineering and Management, 7, 101-112.

[35] Halwatura, R.U. and Pathiranage, Y. (2010) Factors Influencing the Duration of Road Construction Projects in Sri Lanka. Journal of the Institution of Engineers, Sri Lanka, 43, 17-30. https://doi.org/10.4038/engineer.v43i4.6997

[36] Friedman, A.L. and Miles, S. (2002) Developing Stakeholder Theory. Journal of Management Studies, 39, 1-21. https://doi.org/10.1111/1467-6486.00280

[37] Hillman, A.J. and Keim, G.D. (2001) Shareholder Value, Stakeholder Management, and Social Issues: What's the Bottom Line? Strategic Management Journal, 22, 125-139. https://doi.org/10.1002/1097-0266(200101)22:2\%3C125::AID-SMJ150\%3E3.0.CO;2$\underline{\mathrm{H}}$

[38] Bourne, L. and Walker, D.H.T. (2005) Visualizing and Mapping Stakeholder Influ- 
ence. Management Decision, 43, 649-660.

https://doi.org/10.1108/00251740510597680

[39] Gatotoh, A.M., Keiyoro, P.N. and Gakuu, C.M. (2017) Learner Characteristics: Antecedents for mLearning Adoption among Community Health Trainees, Kenya. International Journal of Scientific Research and Innovative Technology, 4, 80-89.

[40] Gay, L.R. and Airasian, P. (2001) Educational Research: Competencies for Analysis and Application. 7th Edition, Merrill/Prentice Hall, Upper Saddle River.

[41] Gliem, J.A. and Gliem, R.R. (2003) Calculating, Interpreting, and Reporting Cronbach's Alpha Reliability Coefficient for Likert-Type Scales. 2003 Midwest Research to Practice Conference in Adult, Continuing, and Community Education, Columbus, 8-10 October 2003, 82-88.

https://scholarworks.iupui.edu/bitstream/handle/1805/344/Gliem\%20\%26\%20Glie m.pdf? sequence $=1$ \&isAllowed $=y$

[42] Mugenda, Q.M. and Mugenda, A.G. (2009) Research Methods: Quantitative and Qualitative Approaches. ACTS, Nairobi.

[43] Kothari, C.R. (2007) Research Methodology: Methods and Techniques. New Age International (P) Ltd., New Delhi. 